\title{
ANALISIS KUALITAS PELAYANAN JASA GO-RIDE DENGAN METODE KANO DAN QUALITY FUNCTION DEPLOYMENT TERHADAP KEPUASAN PELANGGAN (STUDI KASUS PT GO-JEK INDONESIA)
}

\author{
Hermanto $^{1)}$, Elfitria Wiratmani ${ }^{2)}$ \\ ${ }^{1)}$ Program Studi Teknik Industri FTIK Universitas Indraprasta PGRI Jakarta dan \\ Program Pascasarjana Doktor Ilmu Ekonomi Unbor Jakarta \\ ${ }^{2)}$ Program Studi Teknik Industri FTIK Universitas Indraprasta PGRI Jakarta \\ e-mail: hers3sm@gmail.com; ewiratmani@gmail.com
}

\begin{abstract}
ABSTRAK
Tujuan penelitian ini adalah untuk menganalisis apa saja indikator kualitas pelayanan yang dapat mempengaruhi tingkat kepuasan konsumen jasa Go-ride dan mengetahui tingkat kenaikan dan penurunan kepuasan konsumen apabila atribut yang diharapkan konsumen didapat atau tidak dapat. Metode penelitian yang digunakan untuk teknik analisis yaitu Metode Kano dan Quality Function Deployment, Pada pemelitian ini Metode Kano untuk mengkategorikan atribut keinginan konsumen kedalam kategori Kano, Metode Quality Function Deployment dilakukan sampai dengan 3 fase yaitu untuk mencoba mengetahui atribut-atribut pelayanan yang diinginkan konsumen, tingkat kepentingan, tingkat kepuasan konsumen, parameter teknik. Penelitian ini menggunakan kuesioner sebagai instrumen penelitian. Melalui hasil penyebaran kuesioner diketahui 11 atribut keinginan yang dibutuhkan oleh konsumen dan dikelompokkan berdasarkan dimensi Kano. Berdasarkan hasil perhitungan Kano menunjukkan bahwa nilai yang paling tinggi dan yang berpengaruh pada kepuasan konsumen terdapat 2 atribut, dengan nilai Customer Satification sebesar 0.36 terdapat pada atribut nomor 2 dan 11, yaitu pengemudi jujur dan dapat dipercaya, pengemudi selalu bersikap ramah dan sopan pada pelanggan. Dari pembentukan matriks House of Quality (HOQ) diketahui bahwa atribut "pengemudi selalu bersikap ramah dan sopan pada pelanggan” menjadi prioritas utama perbaikan degan nilai tingkat kepentingan 13,0\%.
\end{abstract}

Kata kunci: Kepuasan Konsumen Terhadap Kualitas Pelayanan.

\begin{abstract}
The purpose of this study was to analyze any indicators of service quality that can affect the level of customer satisfaction Go-ride services and determine the level of increase and decrease in customer satisfaction if the attributes expected by consumers are obtained or can not. The research method used for the analysis technique is the canoe method and Quality Function Deployment. In this research, the Kano method to categorize the attributes of consumer desires into the category of Canoe, the Quality Function Deployment method is carried out up to 3 phases, namely to try to find out the service attributes desired by consumers, level of importance, level of customer satisfaction, technical parameters. This study uses a questionnaire as a research instrument. Through the results of the distribution of questionnaires known 11 desires attributes needed by consumers and grouped by Kano dimensions. Based on the results of Kano calculations show that the highest value and the effect on customer satisfaction there are 2 attributes, with a value of Customer Satification of 0.36 contained in attributes number 2 and 11, namely the driver is honest and trustworthy, the driver is always friendly and polite to the customer. From the formation of the House of Quality (HOQ) matrix, it is known that the attribute "the driver is always friendly and polite to customers" is the top priority for improvement with a value of $13.0 \%$ importance.
\end{abstract}

Keywords: Consumer Satisfaction of Service Quality.

\section{PENDAHULUAN}

Sebagai suatu perusahaan swasta tentu saja Go-jek hadir untuk mendapatkan keuntungan sekaligus memberikan lapangan kerja bagi rakyat indonesia, Go-jek memberikan gambaran yang jelas terkait dengan tarif harga service layanannya Supaya tidak menimbulkan keraguan oleh para mitranya, di bawah ini adalah informasi pendapatan driver Go-jek di tiap kota (Tabel 1). 
Tabel 1. Tarif Layanan Go-Jek Di Tiap Kota

\begin{tabular}{ll}
\hline \multicolumn{1}{c}{ Kota } & \multicolumn{1}{c}{ Tarif } \\
\hline Jabodetabek & $0-10 \mathrm{~km}=\mathrm{Rp} .2 .000 / \mathrm{km}$ dari km pertama $>10 \mathrm{~km}=\mathrm{Rp} .3 .000 / \mathrm{km}$ dari $\mathrm{km}$ \\
Tegal & Rp. $1.300 / \mathrm{km}$ dari km pertama Dengan pendapatan minimum Rp. 7.000 \\
Sukabumi, Malang, Surabaya, & Rp. $2.000 / \mathrm{km}$ dari km pertama Dengan pendapatan minimum Rp. 8.000 \\
Sidoarjo, Gresik, Medan, Batam & \\
Sumedang, Mojokerto, Banda Aceh & Rp. $2.000 / \mathrm{km}$ dari km pertama Dengan pendapatan minimum Rp. 8.000 \\
Probolinggo, Belitung & Rp. $2.000 / \mathrm{km}$ dari km pertama Dengan pendapatan minimum Rp. 7.000 \\
\hline
\end{tabular}

Tujuan dari Analisis Kepuasan Konsumen Terhadap Kualitas Pelayanan Jasa Go-ride adalah: Untuk mengetahui apa saja atribut-atribut pelayanan jasa Go-ride yang paling berpengaruh terhadap kepuasan konsumen. Untuk mengetahui prioritas atribut pelayanan yang harus dikembangkan untuk meningkatkan kepuasan konsumen jasa Go-ride. Manfaat yang diharapkan dari penelitian yang dilakukan adalah: Sebagai masukan untuk mengevaluasi, mengembangkan dan meningkatkan kualitas pelayanan jasa Go-ride. hasil penelitian diharapkan dapat menjadi dokumen yang berguna untuk dijadikan acuan bagi siapa saja. Dapat menambah pengetahuan dan wawasan serta dapat mengaplikasikan dan mensosialisasikan teori yang telah diperoleh selama penelitian tersebut.

\section{METODE PENELITIAN}

Metode yang digunakan dalam penelitian ini yaitu Metode Kano, Metode Kano dapat secara optimal dikembangkan dengan model QFD (Quality Function Deployment).

\section{Model Kano}

Model Kano merupakan salah satu cara yang dapat digunakan untuk mengidentifikasi kepuasan konsumen, pada dasarnya Model Kano terdiri dari tiga kategori, tetapi respon konsumen selalu muncul kategori Indifferent, Questionable, Reverse [1].

1) Reverse; Kategori ini merupakan kebalikan dari kategori one dimensional, yaitu derajat kepuasan konsumen lebih tinggi jika layanan berlangsung tidak semestinya, bila dibandingkan kepuasan terhadap layanan yang berjalan dengan baik.

2) Indifferent; Ini merupakan kategori yang tidak memberikan pengaruh pada kepuasan konsumen.

3) Questionable; merupakan kondisi yang kadangkala konsumen puas atau tidak puas jika layanan itu diberikan atau tidak diberikan.

\section{QFD (Quality Function Deployment)}

Menurut Nasution Quality Function Deployment adalah suatu proses atau mekanisme terstruktur untuk menentukan kebutuhan konsumen dan menerjemahkan kebutuhankebutuhan itu ke dalam kebutuhan teknis yang relevan, dimana masing-masing area fungsional dan level organisasi dapat mengerti dan bertindak [2].

Tahapan-tahapan pengimplementasian Quality Function Deployment (QFD) secara umum ada tiga fase:

a. Tahap pengumpulan Voice of Custome (Mengumpulkan Suara Konsumen).

b. Tahap penyusunan rumah kualitas (House of Quality).

c. Tahap analisa dan implementasi.

\section{Metode Pengumpulan Data}

Teknik pengambilan data dalam penelitian ini menggunakan metode survei. tahap pertama yang harus dilakukan dalam penelitian ini adalah konsumen yang pernah melakukan perjalanan menggunakan jasa Go-ride, yaitu para pelajar, mahasiswa dan karyawan di wilayah Jakarta Selatan dan Depok. 


\section{Populasi}

Populasi adalah wilayah generalisasi yang terdiri atas obyek/subyek yang mempunyai kualitas dan karakteristik tertentu yang ditetapkan oleh peneliti untuk dipelajari dan kemudian ditarik kesimpulannya [3]. Dalam penelitian ini yang menjadi populasi adalah order pada bulan maret yang berjumlah 46 order.

\section{Sampel}

Sampel adalah bagian dari jumlah dan karakteristik yang dimiliki oleh populasi tersebut [3]. Untuk sampel yang diambil dari populasi harus betul-betul representative (mewakili).

\section{Teknik Pengambilan Sampel}

Teknik pengambilan sampel dalam penelitian ini menggunakan metode purposive sampling, Adapun kriteria sampel dari penelitian ini adalah konsumen yang pernah menggunakan jasa Go-ride lebih dari 2 kali.Untuk menentukan ukuran sampel dari suatu populasi digunakan rumus Slovin [4].

$$
\begin{aligned}
& n=\frac{\mathrm{N}}{1+N e^{2}} \\
& n=\frac{46}{1+\left(46 \times 0,05^{2}\right)}=41,25
\end{aligned}
$$

Keterangan:

$$
\begin{aligned}
& n: \text { ukuran Sampel } \\
& \mathrm{N}: \text { ukuran populasi } \\
& \mathrm{e}: \text { : persentasi kelonggaran }
\end{aligned}
$$

ketidaktelitian karena kesalahan pengambilan sampel (5\%) Jadi jumlah sampel yang diambil adalah: Maka berdasarkan hasil di atas sampel yang diambil untuk penelitian ini adalah sebanyak 42 responden.

\section{Teknik Analisa Data}

Dalam penelitian ini data yang terkumpul dilakukan analisis reliabilitas untuk uji validitas dan uji reliabilitas. Analisis reliabilitas digunakan untuk mengetahui konsistensi alat ukur berupa kuesioner, skala, atau angket; apakah alat ukur tersebut akan mendapatkan pengukuran yang tetap konsisten jika pengukuran diulang kembali. Selain itu, analisis ini digunakan untuk mengukur validitas item butir pertanyaan dengan teknik Corrected Item Total Correlation, yaitu mengorelasikan antara skor item dengan total item, kemudian melakukan koreksi terhadap nilai koefisien korelasi [5]. Analisa Selanjutnya setelah dilakukan pengujian validitas dan reliabilitas, Dari hasil perhitungan dan analisa pengklasifikasian kategori Kano maka diperoleh jumlah atau nilai kategori kano tiap-tiap atribut keinginan konsumen. Setelah mengetahui kategori dari tiap atribut, maka dilakukan penghitungan dengan menggunakan rumus CS-Coefficient untuk mengetahui atribut mana yang paling berpengaruh atau dominan terhadap kepuasan dan ketidakpuasan konsumen.

Berdasarkan perolehan hasil dari metode Kano, langkah selanjutnya memasuki tahap perancangan kualitas layanan dengan metode Quality Function Deployment, Langkahlangkah dalam Analisa Quality Function Deployment meliputi: Menetapkan derajat kepentingan atribut pelayanan Go-ride, Menetapkan Kinerja Atribut pelayanan Go-ride, Nilai Sasaran Atribut pelayanan Go-ride (goals), Menetapkan Rasio Perbaikan, Menetapkan Sales Point, Menetapkan Bobot Atribut pelayanan Go-ride, Menetapkan Normalisasi Bobot Atribut pelayanan Go-ride, Pembuatan Respon Teknis, Menentukan Hubungan Respon Teknis dengan Kebutuhan Konsumen, Fase Analisa dan Interpretasi [6]. 


\section{HASIL DAN PEMBAHASAN}

\section{Pembahasan dan Analisis}

Pengolahan Selanjutnnya setelah mendapatkan hasil jawaban kuesioner dari responden dimasukan ke dalam 6 kategori model kano (Tabel 2).

Tabel 2. Analisis Kuesioner Kano

\begin{tabular}{|c|c|c|c|c|c|c|}
\hline & & \multicolumn{5}{|c|}{ Disfungsional } \\
\hline & & $\begin{array}{l}\tilde{\Xi} \\
\tilde{\Xi}\end{array}$ & 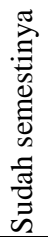 & 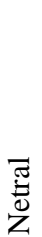 & 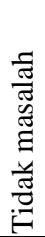 & 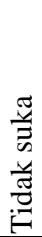 \\
\hline & Suka & $\mathrm{Q}$ & $\mathrm{A}$ & A & $\mathrm{A}$ & $\mathrm{Q}$ \\
\hline$\tilde{\Xi}$ & Sudah semestinya & $\mathrm{R}$ & I & I & I & M \\
\hline 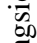 & Netral & $\mathrm{R}$ & I & I & I & M \\
\hline$\Xi$ & Tidak masalah & $\mathrm{R}$ & I & I & I & M \\
\hline & Tidak suka & $\mathrm{R}$ & $\mathrm{R}$ & $\mathrm{R}$ & $\mathrm{R}$ & Q \\
\hline
\end{tabular}

Keterangan: $\mathrm{M}=$ Must-be; $\quad \mathrm{A}=$ Attractive; $\quad \mathrm{R}=$ Reverse;

$\mathrm{O}=$ One-dimensional; $\quad \mathrm{I}=$ Indifferent $; \quad \mathrm{Q}=$ Questionable .

1. Penentuan Kategori Kano untuk Tiap Atribut Seluruh Responden

Kombinasi jawaban dari pertanyaan fungsional dan disfungsional akan menghasilkan klasifikasi kategori kano berdasarkan jawaban kuesioner pengelompokkan pertanyaan dari fungsional dan disfungsional (Tabel 3).

Tabel 3. Analisis Kuesioner Kano Atribut ke 1

\begin{tabular}{|c|c|c|c|c|c|c|c|c|}
\hline \multirow{2}{*}{\multicolumn{2}{|c|}{$\begin{array}{c}\text { Customer } \\
\text { Requirement }\end{array}$}} & \multicolumn{5}{|c|}{ Disfungsional } & \multirow{2}{*}{$\frac{\mathrm{A}}{\mathrm{M}}$} & \multirow{2}{*}{$\frac{2}{25}$} \\
\hline & & 1 & 2 & 3 & 4 & 5 & & \\
\hline \multirow{5}{*}{ 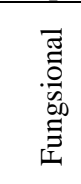 } & 1 & 0 & 0 & 1 & 1 & 1 & $\overline{\mathrm{R}}$ & 0 \\
\hline & 2 & 0 & 0 & 3 & 8 & 25 & $\mathrm{O}$ & 1 \\
\hline & 3 & 0 & 0 & 0 & 3 & 0 & Q & 0 \\
\hline & 4 & 0 & 0 & 0 & 0 & 0 & I & 14 \\
\hline & 5 & 0 & 0 & 0 & 0 & 0 & Total & 42 \\
\hline
\end{tabular}

Sumber: Pengolahan data

\section{Kualifikasi Preferensi Konsumen dengan Model Kano}

Adapun hasil tabulasi evaluasi preferensi konsumen berikut klasifikasi kategorinya pada Tabel 4.

Tabel 4. Perhitungan Kuesioner Kano

\begin{tabular}{cccccccccc}
\hline $\begin{array}{c}\text { Customer } \\
\text { Requirement }\end{array}$ & A & M & O & R & Q & I & Total & Max & Kategori \\
\hline 1 & 2 & $\mathbf{2 5}$ & 1 & 0 & 0 & 14 & 42 & $\mathbf{2 5}$ & M \\
2 & 8 & $\mathbf{1 9}$ & 7 & 0 & 0 & 8 & 42 & $\mathbf{1 9}$ & M \\
3 & 1 & $\mathbf{2 1}$ & 6 & 0 & 0 & 14 & 42 & $\mathbf{2 1}$ & M \\
4 & 3 & $\mathbf{2 4}$ & 4 & 0 & 0 & 11 & 42 & $\mathbf{2 4}$ & M \\
5 & 3 & $\mathbf{2 5}$ & 3 & 0 & 0 & 11 & 42 & $\mathbf{2 5}$ & M \\
6 & 1 & $\mathbf{2 6}$ & 3 & 0 & 0 & 12 & 42 & $\mathbf{2 6}$ & M \\
7 & 5 & $\mathbf{2 2}$ & 6 & 0 & 0 & 9 & 42 & $\mathbf{2 2}$ & M \\
8 & 5 & $\mathbf{2 2}$ & 6 & 0 & 0 & 9 & 42 & $\mathbf{2 2}$ & M \\
9 & 1 & $\mathbf{2 5}$ & 5 & 0 & 0 & 11 & 42 & $\mathbf{2 5}$ & M \\
10 & 2 & $\mathbf{2 4}$ & 4 & 0 & 0 & 12 & 42 & $\mathbf{2 4}$ & M \\
11 & 5 & $\mathbf{1 7}$ & 10 & 0 & 0 & 10 & 42 & $\mathbf{1 7}$ & M \\
\hline
\end{tabular}

Sumber: Pengolahan Data

Setelah mengetahui kategori dari tiap atribut, maka dilakukan penghitungan dengan menggunakan rumus CS-Coefficient untuk mengetahui atribut mana yang paling berpengaruh atau dominan terhadap kepuasan (Customer Satification) dan ketidakpuasan (Customer Dissatification) konsumen, berdasarkan rumus di bawah ini, yaitu: 


$$
\begin{aligned}
& C S=\frac{A+O}{A+O+M+I} \\
& D S=-\frac{O+M}{A+O+M+I}
\end{aligned}
$$

\section{Menghitung Nilai CS dan DS}

CS (Customer Satification) mengidentifikasikan bahwa kepuasan konsumen akan semakin meningkat jika perusahaan memenuhi Keinginan Konsumen (Customer Requirement/CR) tersebut. Sebaliknya untuk DS (Customer Dissatification) mengidentifikasikan bahwa ketidakpuasan konsumen akan semakin meningkat apabila perusahaan memenuhi keinginan konsumen tersebut (Tabel 5). Hasil Atribut dapat dilihat Tabel 6.

Tabel 5. Perhitungan Nilai CS dan DS

\begin{tabular}{cccccccccc}
\hline $\begin{array}{c}\text { Customer } \\
\text { Requirement }\end{array}$ & $\mathbf{A}$ & $\mathbf{M}$ & $\mathbf{O}$ & $\mathbf{R}$ & $\mathbf{Q}$ & $\mathbf{I}$ & Total & CS & DS \\
\hline 1 & 2 & 25 & 1 & 0 & 0 & 14 & 42 & 0.07 & -0.62 \\
2 & 8 & 19 & 7 & 0 & 0 & 8 & 42 & 0.36 & -0.62 \\
3 & 1 & 21 & 6 & 0 & 0 & 14 & 42 & 0.17 & -0.64 \\
4 & 3 & 24 & 4 & 0 & 0 & 11 & 42 & 0.17 & -0.67 \\
5 & 3 & 25 & 3 & 0 & 0 & 11 & 42 & 0.14 & -0.67 \\
6 & 1 & 26 & 3 & 0 & 0 & 12 & 42 & 0.10 & -0.69 \\
7 & 5 & 22 & 6 & 0 & 0 & 9 & 42 & 0.26 & -0.67 \\
8 & 5 & 22 & 6 & 0 & 0 & 9 & 42 & 0.26 & -0.67 \\
9 & 1 & 25 & 5 & 0 & 0 & 11 & 42 & 0.14 & -0.71 \\
10 & 2 & 24 & 4 & 0 & 0 & 12 & 42 & 0.14 & -0.67 \\
11 & 5 & 17 & 10 & 0 & 0 & 10 & 42 & 0.36 & -0.64 \\
\hline
\end{tabular}

Sumber: Pengolahan Data

\begin{tabular}{|c|c|c|c|c|c|c|c|c|}
\hline No & Atribut & $\begin{array}{c}\text { Derajat } \\
\text { Kepentingan }\end{array}$ & Kinerja & $\begin{array}{c}\text { Nilai } \\
\text { Sasaran }\end{array}$ & $\begin{array}{l}\text { Sales } \\
\text { Point }\end{array}$ & $\begin{array}{c}\text { Rasio } \\
\text { perbaikan }\end{array}$ & Bobot & $\begin{array}{c}\text { Normalitas } \\
\text { Bobot }\end{array}$ \\
\hline 1 & $\begin{array}{l}\text { Pengemudi menggunakan motor } \\
\text { yang baik dan layak }\end{array}$ & 4.071 & 4.095 & 5 & 1.5 & 1.221 & 7.456 & 9.955 \\
\hline 3 & $\begin{array}{l}\text { Pengemudi selalu menjaga } \\
\text { penampilan }\end{array}$ & 4.214 & 4.024 & 4 & 1.5 & 0.994 & 6.284 & 8.390 \\
\hline 4 & $\begin{array}{l}\text { Pengemudi menawarkan fasilitas } \\
\text { pada pelanggan (Masker, Jas hujan } \\
\text { bila hujan) }\end{array}$ & 4.048 & 4.238 & 5 & 1.5 & 1.180 & 7.163 & 9.563 \\
\hline 5 & Pengemudi berkendara dengan baik & 4.048 & 3.881 & 4 & 1.5 & 1.031 & 6.258 & 8.354 \\
\hline 6 & $\begin{array}{l}\text { Pengemudi selalu mengantarkan } \\
\text { pelanggan dengan cepat dan aman }\end{array}$ & 4.048 & 4.095 & 5 & 1.5 & 1.221 & 7.413 & 9.897 \\
\hline 7 & $\begin{array}{l}\text { Perusahaan peduli terhadap keluhan } \\
\text { pelanggan }\end{array}$ & 4.000 & 4.286 & 5 & 1.5 & 1.167 & 7.000 & 9.346 \\
\hline 10 & $\begin{array}{l}\text { konfirmasi pesanan melalui chat atau } \\
\text { telefon }\end{array}$ & 4.024 & 3.786 & 4 & 1.5 & 1.057 & 6.377 & 8.514 \\
\hline 11 & $\begin{array}{l}\text { Pengemudi selalu bersikap ramah } \\
\text { dan sopan pada pelanggan }\end{array}$ & 4.048 & 4.048 & 4 & 1.5 & 0.988 & 6.000 & 8.010 \\
\hline
\end{tabular}

Tabel. 6. Atribut

Untuk menggambarkan tingkat hubungan antara masing-masing karakteristik pelayanan yang ada digunakan simbol sebagai berikut:
- = tingkat hubungan positif kuat
$\square=$ tingkat hubungan positif sedang
$-\quad=$ tingkat hubungan positif sedang
$\boldsymbol{\Delta}=$ tingkat hubungan negatif kuat
$\Delta=$ tingkat hubungan negatif sedang 
Analisis Kualitas Pelayanan Jasa Go-ride dengan Metode Kano dan Quality Function Deployment Terhadap Kepuasan Pelanggan (Studi Kasus PT Go-jek Indonesia)

\section{Hermanto, Elfitria Wiratmani}

Tingkat hubungan antara masing-masing karakteristik pelayanan dapat dilihat pada Gambar 1.

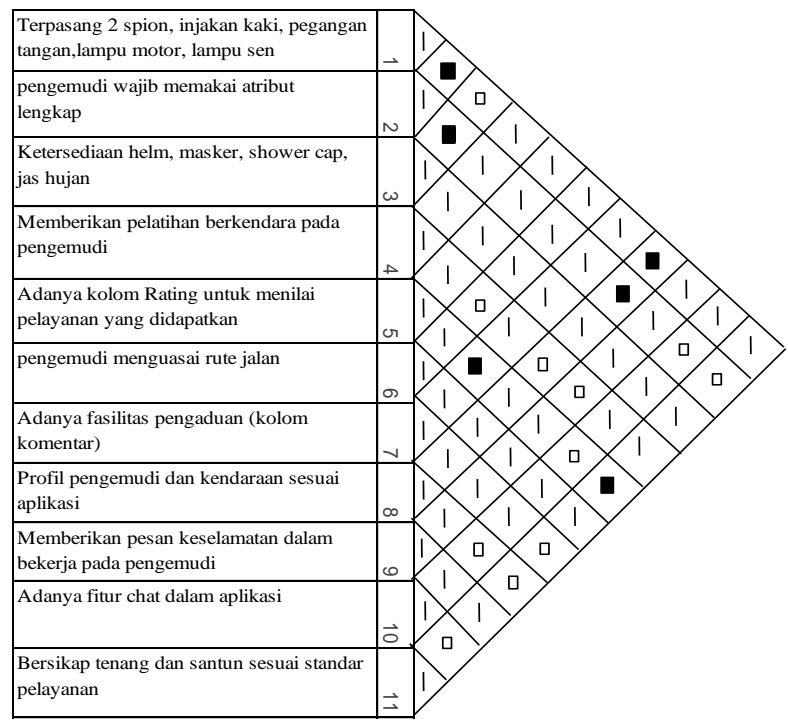

Gambar 1. Hubungan Korelasi antar Karakteristik Pelayanan

Matrik interaksi, tahap ini bertujuan untuk mengetahui keeratan hubungan antar komponen persyaratan teknis dalam memenuhi keinginan konsumen (Tabel 7). Adapun tipe hubungan yang digunakan yaitu:

$$
\begin{aligned}
& \text { - }=\text { tingkat hubungan kuat dengan nilai } 9 \\
& \bullet=\text { tingkat hubungan sedang dengan nilai } 3 \\
& \mathbf{\Delta}=\text { tingkat hubungan lemah dengan nilai } 1
\end{aligned}
$$

\begin{tabular}{|c|c|c|c|c|c|c|c|c|c|c|c|c|}
\hline & Functional Requirements & 1 & 2 & 3 & 4 & 5 & 6 & 7 & 8 & 9 & 10 & 11 \\
\hline 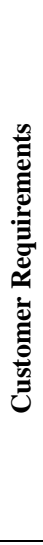 & & 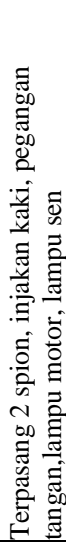 & 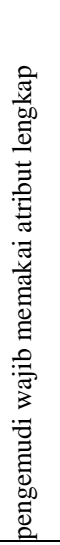 & 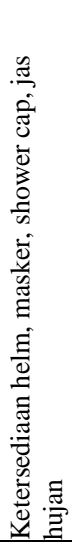 & 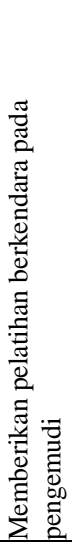 & 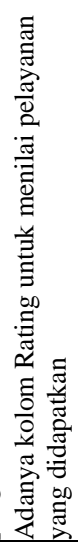 & 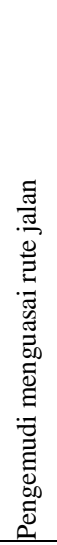 & 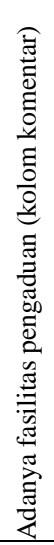 & 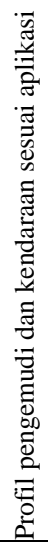 & 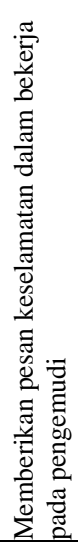 & 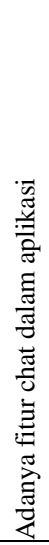 & 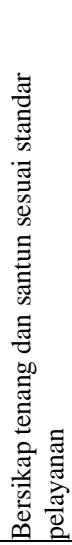 \\
\hline 1 & Pengemudi menggunakan motor yang baik dan layak & $\square$ & & & & & & & $\Delta$ & & & \\
\hline 2 & Pengemudi jujur dan dapat dipercaya & & $\boldsymbol{\Delta}$ & & & & & & $\bullet$ & & & $\boldsymbol{\Delta}$ \\
\hline 3 & Pengemudi selalu menjaga penampilan & & $\mathbf{\square}$ & & & & & & & & & \\
\hline 4 & $\begin{array}{l}\text { Pengemudi menawarkan fasilitas pada pelanggan } \\
\text { (Masker, Jas hujan bila hujan) }\end{array}$ & & & ש & & & & & & & & \\
\hline 5 & Pengemudi berkendara dengan baik & & & & $\mathbf{n}$ & & $\boldsymbol{\Delta}$ & & & - & & \\
\hline 6 & $\begin{array}{l}\text { Pengemudi selalu mengantarkan pelanggan dengan } \\
\text { cepat dan aman }\end{array}$ & & & & & & • & & & & & 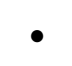 \\
\hline 7 & Perusahaan peduli terhadap keluhan pelanggan & & & & & - & & n & & & & \\
\hline 8 & Pengemudi tanggap terhadap permintaan pelanggan & & & • & & • & & & & & & $\Delta$ \\
\hline 9 & $\begin{array}{l}\text { Pengemudi selalu memberikan saran rute perjalanan } \\
\text { yang terbaik }\end{array}$ & & & & & & $\mathbf{\square}$ & & & & & \\
\hline 10 & $\begin{array}{l}\text { Pengemudi selalu memberikan konfirmasi pesanan } \\
\text { melalui chat atau telefon }\end{array}$ & & & & & & & & & & $\mathbf{\square}$ & \\
\hline 11 & $\begin{array}{l}\text { Pengemudi selalu bersikap ramah dan sopan pada } \\
\text { pelanggan }\end{array}$ & & & & & • & & & & & & \\
\hline
\end{tabular}

Tabel 7. Interaksi Keinginan Konsumen dengan Parameter Teknik (berupa simbol) 
Interaksi Keinginan Konsumen dengan Parameter Teknik (berupa angka), dapat dilihat Tabel 8.

Tabel 8. Interaksi Keinginan Konsumen dengan Parameter Teknik (berupa angka)

\begin{tabular}{|c|c|c|c|c|c|c|c|c|c|c|c|c|}
\hline & Functional Requirements & 1 & 2 & 3 & 4 & 5 & 6 & 7 & 8 & 9 & 10 & 11 \\
\hline 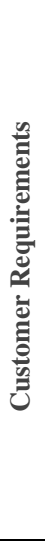 & & 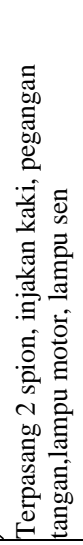 & 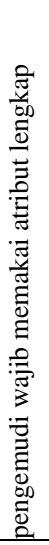 & 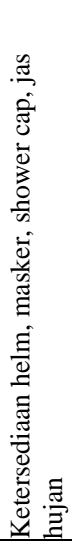 & 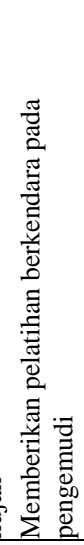 & 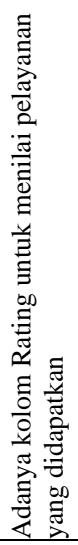 & 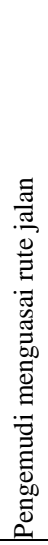 & 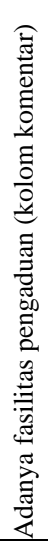 & 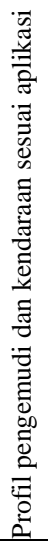 & 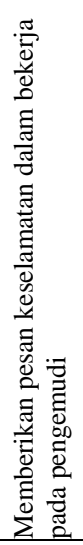 & 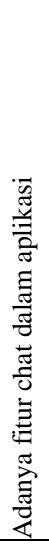 & 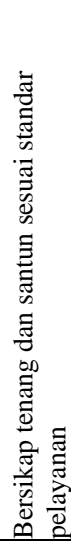 \\
\hline 1 & Pengemudi menggunakan motor yang baik dan layak & 9 & & & & & & & 1 & & & \\
\hline 2 & Pengemudi jujur dan dapat dipercaya & & 1 & & & & & & 3 & & & 1 \\
\hline 3 & Pengemudi selalu menjaga penampilan & & 9 & & & & & & & & & \\
\hline 4 & $\begin{array}{l}\text { Pengemudi menawarkan fasilitas pada pelanggan } \\
\text { (Masker, Jas hujan bila hujan) }\end{array}$ & & & 9 & & & & & & & & \\
\hline 5 & Pengemudi berkendara dengan baik & & & & 9 & & 1 & & & 3 & & \\
\hline 6 & $\begin{array}{l}\text { Pengemudi selalu mengantarkan pelanggan dengan } \\
\text { cepat dan aman }\end{array}$ & & & & 3 & & 3 & & & & & 3 \\
\hline 7 & Perusahaan peduli terhadap keluhan pelanggan & & & & & 3 & & 9 & & & & \\
\hline 8 & Pengemudi tanggap terhadap permintaan pelanggan & & & 3 & & 3 & & & & & & 1 \\
\hline 9 & $\begin{array}{l}\text { Pengemudi selalu memberikan saran rute perjalanan } \\
\text { yang terbaik }\end{array}$ & & & & & & 9 & & & & & \\
\hline 10 & $\begin{array}{l}\text { Pengemudi selalu memberikan konfirmasi pesanan } \\
\text { melalui chat atau telefon }\end{array}$ & & & & & & & & & & 9 & \\
\hline 11 & $\begin{array}{l}\text { Pengemudi selalu bersikap ramah dan sopan pada } \\
\text { pelanggan }\end{array}$ & & & & & 3 & & & & & & 9 \\
\hline
\end{tabular}

\section{Analisis Model Kano}

Berdasarkan jawaban kuesioner pengelompokan pertanyaan fungsional dan disfungsional Model Kano, didapatkan bahwa 11 atribut pelayanan yaitu pengemudi menggunakan motor yang baik dan layak, pengemudi jujur dan dapat dipercaya, pengemudi selalu menjaga penampilan, pengemudi menawarkan fasilitas pada pelanggan (masker, jas hujan bila hujan), pengemudi berkendara dengan baik, pengemudi selalu mengantarkan pelanggan dengan cepat dan aman, perusahaan peduli terhadap keluhan pelanggan, Pengemudi tanggap terhadap permintaan pelanggan, pengemudi selalu memberikan saran rute perjalanan yang terbaik, pengemudi selalu memberikan konfirmasi pesanan melalui chat atau telefon, Pengemudi selalu bersikap ramah dan sopan pada pelanggan masuk kategori Must be.

\section{Analisis House of Quality (HOQ)}

Dari hasil penelitian matrik House of Quality (HOQ) di atas, keinginan konsumen dalam bentuk atribut jasa diterjemahkan dalam bahasa teknik oleh manajemen dalam bentuk Customer Requirement. Berikut ini adalah pembahasan tentang hasil penelitian analisis kepuasan konsumen terhadap kualitas pelayanan jasa Go-ride dengan Metode Kano dan Quality Function Deployment:

a. Derajat Kepentingan Atribut Jasa

Berdasarkan hasil kuesioner terdapat 4 atribut jasa yang sangat penting antara lain: pengemudi menggunakan motor yang baik dan layak, pengemudi selalu menjaga 


\section{Hermanto, Elfitria Wiratmani}

penampilan, pengemudi menawarkan fasilitas pada pelanggan (masker, jas hujan bila hujan), pengemudi berkendara dengan baik.

\section{b. Kinerja Atribut Jasa}

Berdasarkan hasil kuesioner terdapat 3 atribut jasa yang memiliki kinerja yang sangat baik yaitu: perusahaan peduli terhadap keluhan pelanggan, pengemudi selalu memberikan saran rute perjalanan yang terbaik, pengemudi selalu bersikap ramah dan sopan pada pelanggan.

\section{c. Nilai Target}

Nilai target untuk setiap atribut jasa diberikan point 4 dan 5 agar pelayanan dapat diberikan secara baik bahkan sampai sangat baik.

\section{d. Bobot Atribut Jasa dan Normalisasi Bobot Atribut Jasa}

Perusahaan peduli terhadap keluhan pelanggan, pengemudi selalu memberikan saran rute perjalanan yang terbaik, pengemudi selalu bersikap ramah dan sopan pada pelanggan, pengemudi menggunakan motor yang baik dan layak, pengemudi selalu menjaga penampilan, pengemudi menawarkan fasilitas pada pelanggan (masker, jas hujan bila hujan), pengemudi berkendara dengan baik.

\section{e. Hubungan antara Karakteristik Pelayanan}

Berdasarkan Gambar 1 terdapat hubungan positif kuat antara parameter teknik nomor 1 dengan 2, nomor 1 dengan 8, nomor 2 dengan 8, nomor 5 dengan 7, nomor 5 dengan 11 . Terdapat hubungan positif sedang antara parameter teknik nomor 1 dengan 3 , nomor 2 dengan 10, nomor 2 dengan 11, nomor 4 dengan 6 , nomor 4 dengan 8 , nomor 4 dengan 9 , nomor 5 dengan 10, nomor 7 dengan 11, nomor 8 dengan 10, nomor 8 dengan 11, nomor 10 dengan 11.

\section{f. Matrik Interaksi Keinginan Konsumen dengan Parameter Teknik}

Hubungan yang terjadi antara atribut pelayanan dengan parameter teknik berupa tingkat hubungan kuat dengan nilai 9, tingkat hubungan sedang dengan nilai 3, dan yang terakhir adalah tingkat hubungan lemah dengan nilai 1 . Nilai parameter tertinggi adalah nilai bersikap tenang dan santun sesuai standar pelayanan yaitu 121,5 hal ini disebabkan karena ada empat atribut yang berhungan dengan kebutuhan teknis ini yaitu pengemudi jujur dan dapat dipercaya, pengemudi selalu mengantarkan pelanggan dengan cepat dan aman, pengemudi tanggap terhadap permintaan pelanggan, dan pengemudi selalu bersikap ramah dan sopan pada pelanggan. Sedangkan yang terendah adalah memberikan pesan keselamatan dalam bekerja pada pengemudi yaitu 25,1 .

\section{g. Prioritas Perbaikan Pelayanan}

Dari kesebelas parameter teknik prioritas utamanya adalah Bersikap tenang dan santun sesuai standar pelayanan $(13,0 \%)$, Ketersediaan helm, masker, shower cap, jas hujan $(12,4 \%)$, pengemudi menguasai rute jalan (12,0\%), Memberikan pelatihan berkendara pada pengemudi $(11,2 \%)$ Terpasang 2 spion, injakan kaki, pegangan tangan,lampu motor, lampu sen $(9,6 \%)$, pengemudi wajib memakai atribut lengkap $(9,1 \%)$, Adanya fasilitas pengaduan (kolom komentar) $(9,0 \%)$, Adanya kolom Rating untuk menilai pelayanan yang didapatkan $(8,7)$, Adanya fitur chat dalam aplikasi $(8,2 \%)$, Profil pengemudi dan kendaraan sesuai aplikasi $(4,2)$, Memberikan pesan keselamatan dalam bekerja pada pengemudi $(2,7 \%)$. 


\section{KESIMPULAN}

Berdasarkan hasil perhitungan Kano menunjukkan bahwa nilai yang paling tinggi dan yang berpengaruh pada kepuasan konsumen terdapat 2 atribut, dengan nilai Customer Satification sebesar 0.36 terdapat pada atribut nomor 2 dan 11, yaitu pengemudi jujur dan dapat dipercaya, pengemudi selalu bersikap ramah dan sopan pada pelanggan. Prioritas atribut pelayanan yang perlu perbaikan adalah pengemudi selalu memberikan konfirmasi pesanan melalui chat atau telefon karena memiliki bobot tingkat kepentingan yang terbesar yaitu $13,10 \%$. Berdasarkan penelitian yang telah dilakukan, maka penulis mencoba memberikan saran dan masukan yang dapat berguna pelayanan jasa Go-ride perlu dilakukan perbaikan sesuai dengan kategorinya. Hal ini berarti berdasarkan persepsi pelanggan, ada beberapa atribut pelayanan yang belum memenuhi apa yang menjadi kebutuhan/ keinginan pelanggan. Hasil analisis tingkat kepentingan berada pada prioritas cukup penting hingga sangat penting sehingga PT. Go-jek Indonesia harus menindaklanjuti atribut-atribut yang dianggap penting dan belum terpenuhi secara bertahap berdasarkan tingkat kepentingannya masing-masing. PT. Go-jek Indonesia harus melakukan upaya peningkatan kualitas melalui evaluasi dan perbaikan sistem yang ada, meningkatkan kualitas sumber daya manusia, melengkapi atribut-atribut yang belum terdapat dalam layanan.

\section{DAFTAR PUSTAKA}

[1]. Tjiptono, F., 2012, Service Manajemen, Edisi 2. Yogyakarta: Penerbit Andi.

[2]. Dale H. Besterfield, Carol Besterfield-Michna,Glen Besterfield, and Mary Besterfield-Sacre, 2003, Total Quality Management, Pearson Education, International Edition 3, United State.

[3]. Sugiyono., 2015, Statistika Untuk Penelitian. Bandung: Alfabeta Bandung.

[4]. Sujarweni, V. W., 2014, Metodologi Penelitian, Yogyakarta: Gava Media.

[5]. Priyatno, D., 2012, Cara kilat Belajar Analisis Data dengan SPSS 20, Yogyakarta: Penerbit Andi.

[6]. Farida, F. I., 2011, Analisis Kepuasan Pelanggan Terhadap Kualitas Pelayanan Jasa Kereta Api Ekspres Pakuan Jabodetabek, Skripsi, Fakultas Ekonomi Dan Manajemen, Institut Pertanian Bogor, Bogor. 